ECOLOGICA, Vol. 28, No 103 (2021), 355-362

https://doi.org/10.18485/ecologica.2021.28.103.4

Pregledni rad

UDC: 338.484:502.131.1

\title{
Održivi turizam u funkciji privrednog razvoja
}

\section{Sustainable Tourism in the function of Economic Development}

\author{
Amina Hamida A. Khoja ${ }^{1}$, Prof. dr Maja Kovačević2*, \\ Doc. dr Jovana Gardašević3 ${ }^{3}$ Doc. dr Omer Ali Mohamoud ${ }^{4}$ \\ ${ }^{1}$ Ambasada Libije, Sime Lozanića 6, Beograd, Srbija \\ ${ }^{2-4}$ Fakultet za ekonomiju i inženjerski menadžment u Novom Sadu, Cvećarska 2, Novi Sad, Srbija \\ *Autor za prepisku / Corresponding author
}

Rad primljen / Received: 24.12.2020, Rad prihvaćen / Accepted: 09.08.2021.

Sažetak: Održivi razvoj predstavlja složen i kompleksan koncept razvoja, u kome su povezani privredni, socijalni i kulturni razvoj, koji je usklađen sa potrebama i ograničenjima životne sredine. Održivi razvoj se ne bavi samo odnosom privrede i ekologije, on takođe usklađuje ekološki razvoj sa socijalnom politikom na globalnom nivou. Strategije održivog razvoja ukazuju na efekte dugoročnih trendova u oblasti održive proizvodnje i potrošnje. Turizam, kao jedan od najvećih pokretača razvoja svetske privrede, zahteva neophodnost uspostavljanja održivog i odgovornog razvoja, u cilju svih bitnih vrednosti okruženja, s obzirom na to da se današnje društvo susreće sa dva najvažnija problema, klimatskim promenama i siromaštvom. Održivi turizam je najbolji način da se podstakne turistički podsticaj i pospeši lokalni razvoj. Ljudski resursi predstavljaju jedan od osnovnih faktora sa primarnim značajem za organizovanje i razvoj, a na taj način su od velike važnosti i za razvoj preduzeća i organizacija, koje se bave poslovima turizma. Novčana, odnosno investiciona sredstva, čine takođe, jedan od osnovnih faktora u pokretanju razvoja svake delatnosti na nivou regije, a time i razvoju turizma. $U$ fazi sveukupnih promena $u$ ekonomskim odnosima, ali i zahtevima iz okruženja, nosioci privrednih i organizacionih funkcija, našli su se pred velikim iskušenjima. Preduzeća se moraju prestruktuirati, što podrazumeva i novu organizacionu strukturu i promene unutar njih samih. U procesu decentralizacije, sve veća potreba za razvojem, izražena je na lokalnom nivou. $S$ obzirom da moderna i savremena država treba da ima određenu ulogu u podsticaju regionalnog razvoja, značaj i uticaj države je od velikog značaja za podupiranje utvrđene koncepcije razvoja. Kompanije treba da postave organizaciju na način da dostignu svoje ambicije održivosti i na taj način integrišu održivost u organizaciju, odnosno da formiraju višefunkcionalne timove, postavljaju jasne ciljeve i ključne pokazatelje rada. Pitanja održivosti moraju biti integrisana u operativno upravljanje i uzeti u obzir u svim aktivnostima, rutinama i procesima, kako bi se razvila održiva organizacija. Integrisanje održivosti na normativnom nivou mora biti prioritet kompanija. Cilj rada je analiza održivog turizma u funkciji privrednog razvoja, pri čemu pristup održivom razvoju ima značenje novog ekonomskog učenja, metode i politike društveno - ekonomskog razvoja u globalu i naročito je značajan za privredne oblasti.

Ključne reči: održivi turizam, privredni razvoj, preduzeća, turizam, održivi razvoj.

\begin{abstract}
Sustainable development is a complex concept of development, in which economic, social and cultural development are connected, and which is harmonized with the needs and limitations of the environment. Sustainable development does not deal only with the relationship between the economy and the environment, it also harmonizes environmental development with the social policy at the global level. Sustainable development strategies indicate on the effects of long-term trends in the field of sustainable production and consumption. Tourism, as one of the biggest drivers of the development of the world economy, requires the need to establish sustainable and responsible development, in order to achieve all the important values of the environment, given that today's society faces with the two most important problems, climate change and poverty. Sustainable tourism is the best way to encourage tourism incentive and boost local development. Human resources are one of the basic factors of primary importance for organization and development, and thus they are of great importance for the development of companies and organizations in the field of tourism. Cash, ie investment funds, are also one of the basic factors in initiating the
\end{abstract}


development of any activity at the regional level, and thus the development of tourism. In the phase of overall economic relations changes, but also in the demands from the environment, the holders of economic and organizational functions, faced the great temptations. Companies must be restructured, which implies a new organizational structure and changes within themselves. In the process of decentralization, the growing need for development is expressed at the local level. Given that the modern and contemporary state should have a certain role in fostering regional development, the importance and influence of the state is of great importance for supporting the established concept of development. Companies need to set up an organization in a way to achieve their sustainability ambitions and thus integrate sustainability into the organization, ie to form multifunctional teams, set clear goals and key performance indicators. Sustainability issues must be integrated into operational management and taken into account in all activities, routines and processes, in order to develop a sustainable organization. Integrating sustainability at the normative level must be a priority for companies. The aim of this paper is to analyze sustainable tourism in the function of economic development, where the approach to sustainable development has the meaning of new economic learning, methods and policies of socio-economic development in general and is especially important for economic areas.

Key words: sustainable tourism, economic development, enterprises, tourism, sustainable development.

\footnotetext{
${ }^{1}$ orcid.org/0000-0003-2030-2500, e-mail: zakiakhoja@yahoo.com

ºrcid.org/0000-0001-6902-3794, e-mail: majaskovacevic5@gmail.com

${ }^{3}$ orcid.org/0000-0002-3239-2083, e-mail: J.gardasevic@fimek.edu.rs

${ }^{4}$ orcid.org/0000-0001-6644-1237, e-mail: hafshook@yahoo.com
}

\section{UVOD / INTRODUCTION}

U novijem periodu, pojam održivi razvoj u svetu ima značenje novog ekonomskog učenja, metode i politike društveno - ekonomskog razvoja u globalu. Ovaj razvojni pristup naročito je značajan za privredne oblasti. U svakoj privrednoj delatnosti, održivi razvoj treba tretirati kao metod kojim se obezbeđuje povezivanje ekonomskih i ekoloških činilaca. Ovim metodom održivog razvoja, a time i razvoja turizma, usklađuju se ekonomski ciljevi, kroz način korišćenja prirodnih resursa, jer se zasnivanjem i primenom politike održivog razvoja obezbeđuju dugoročne i stabilne osnove da se podstiče prošireno obnavljanje i zaštita obnovljivih prirodnih resursa, u funkciji zaštite globalne životne sredine (Vićentijević i dr., 2011). Primenom metoda održivog razvoja, stvaraju se trajne osnove za racionalno korišćenje prirodnih resursa i energije, kao i za unapređivanje životne sredine u celini. Kao takav, metod održivog razvoja se ispoljava kao jedna od najznačajnijih komponenti, kako privrednog, tako i ukupnog društveno-ekonomskog i socijalnog razvoja.

Osnovne komponente održivog razvoja su: ostvarivanje ekonomskog razvoja, u cilju zadovoljenja glavnih potreba i osiguranja održivog nivoa stanovništva, promena tehnologija i upravljanje rizicima, povezivanje ekonomije i „ekologije“ u donošenju odluka, kao i preorijentacija međunarodnih odnosa (Lukinović i dr., 2017). Održivi razvoj predstavlja proces kojim se zadovoljavaju sadašnji zahtevi i ne dovode u pitanje zahtevi budućih generacija, da zadovolje vlastite potrebe. Održivi razvoj se ne bavi samo odnosom privrede i ekologije, on takođe usklađuje ekološki razvoj sa socijalnom politikom na globalnom nivou. Strategije održivog razvoja ukazuju na efekte dugoročnih trendova u oblasti održive proizvodnje i potrošnje (Ožegović i dr., 2012).

Turizam je u mnogim zemljama prepoznat kao važan faktor ekonomskog razvoja. Jasno je da ekonomski faktor spada u pozitivni efekat turizma, međutim pored pozitivne ekonomske strane, javljaju se i negativni faktori prouzrokovani turističkom eksploatacijom pojedinih područja. Negativni faktori mogu biti ekološke prirode, ali i drušveno-socijalnog karaktera, usled prevelikog pritiska na lokalnu zajednicu, naročito izraženog u letnjoj ili zimskoj sezoni, u zavisnosti od turističkog odredišta.

Iz razloga sve većeg pritiska na prirodne resurse, javlja se potreba da se turizam planira i kontroliše, a koncept održivog razvoja turizma bi trebalo da predstavlja osnovu dugoročnog razvoja, u okviru turističke destinacije. Ovakav oblik razvoja treba da obezbedi zaštitu resursa, da se negativan uticaj turističkih aktivnosti svede na minimum i $u$ tom pogledu, održivi razvoj je ključni instrument za rešavanje ekoloških problema, prouzrokovanim aktivnostima turista.

$S$ tim u vezi, turizam je jedan od najvećih pokretača razvoja svetske privrede. Istraživanja pokazuju da se pred turističku privredu i sve institucije u oblasti turizma, postavlja zadatak održivog i odgovornog razvoja u cilju očuvanja životne sredine kao resursa turističkog proizvoda (Radosavac i dr., 2013). Održivi turizam je najbolji način da se podstakne turistički podsticaj i pospeši lokalni razvoj. Razvoj turizma je 
najbolji, ako je planski i počiva na savremenim zahtevima održivog razvoja.

Ovaj rad je posvećen održivom turizmu kao indikatoru privrednog razvoja. $\mathrm{Na}$ početku rada predstavljen je integralni održivi razvoj, kao i održivi razvoj turizma, kao vid turizma, koji predstavlja niz principa održivosti, koje se mogu primeniti u celom sektoru turizma.

\section{INTEGRALNI ODRŽIVI RAZVOJ / INTEGRAL SUSTAINABLE DEVELOPMENT}

Svaka pojedina lokalna zajednica (selo, grad i opština) ima svoju lokalnu zajednicu razvijanja kapaciteta. Konkurentnost lokalnih zajednica predstavlja sintezu različite vrste glavnih gradova, koje poseduje jedna ili više lokalnih zajednica, upoređujući sa drugim lokalnim zajednicama. Pored njega, ekonomska konkurentnost znači mogućnost neke lokalne zajednice da učestvuje u lokalnom takmičenju, podjednako (Janković i dr., 2017).

Uporedna prednost nekog lokalnog miljea ogleda se u njegovoj mogućnosti stvaranja novih radnih mesta, ulaganja za izgradnju infrastrukture, lokalno preduzetništvo i direktna ulaganja u mala i srednja preduzeća, kao i strategiji razvoja turizma. Samim tim, osnovni dugoročni cilj razvoja lokalne zajednice je usmeren na povećanje kvaliteta života, stvaranja novih radnih mesta, integracije lokalne zajednice u šire regionalne sisteme.

Održivi razvoj podrazumeva da lokalni milje ima određeni nivo učešća i kontrolu nad procesima u razvoju, kao realizacija mogućnosti i dobijanja profita od tog razvoj, a da bi se obezbedio optimalan razvoj, lokalne zajednice moraju da postignu konkurentnost, na više nivoa, u isto vreme (Vujadinović i sar., 2010). $\mathrm{U}$ fazi sveukupnih promena u ekonomskim odnosima, ali i zahtevima iz okruženja, nosioci privrednih i organizacionih funkcija, našli su se pred velikim iskušenjima. Preduzeća se moraju prestrukturirati, što podrazumeva i novu organizacionu strukturu i promene unutar njih samih. $U$ procesu decentralizacije, sve veća potreba za razvojem, izražena je na lokalnom nivou. S obzirom da moderna i savremena država treba da ima određenu ulogu u podsticaju regionalnog razvoja, značaj i uticaj države je od velikog značaja za podupiranje utvrđene koncepcije razvoja (Radygin et al., 2015).

Koncepcija turističkog razvoja, u tom smislu, predstavlja sistem društvenih ciljeva i konkretnih uslova u kojima se odvija razvoj turizma i definisana je strategijom društvenog i ekonomskog razvoja. Nije moguće sprovoditi strategiju turizma koja ne proizilazi iz koncepcije društvenog i ekonomskog razvoja, koju prvenstveno determinišu društveni odnosi i ciljevi, kao i nivo ekonomskog razvoja, strategija privrednog razvoja, specifičnosti delovanja tržišta, razvojni trendovi i drugi faktori (Angelevska-Najdeska, Rakicevik, 2012). U tom smislu, identitet lokalne zajednice, njeno prepoznavanje i komparativna prednost, mogu ojačati međusobno poverenje i saradnju među stanovništvom. S druge strane, zajednički interesi i intenzivirana interaktivnost stanovništva, omogućavaju stvaranje lokalnog identiteta.

Posebnu pažnju treba obratiti na stvaranje važnih činilaca uspešne, a samim tim i inovativne turističke ponude, u nastojanju da se poveća konkurentnost turističkih organizacija. Sve ono što je od značaja za povećanje tržišne konkurentnosti regijske turističke delatnosti, može da se svrsta u istraživačku infrastrukturu, ljudske resurse, kao i veze sa korisnicima usluga, fleksibilnost zakonske regulative, ali i sklonost ka saradnji.

Ljudski resursi predstavljaju jedan od osnovnih faktora sa primarnim značajem za organizovanje i razvoj, a na taj način su od velike važnosti i za razvoj preduzeća i organizacija, koje se bave poslovima turizma. Novčana, odnosno investiciona sredstva, čine takođe, jedan od osnovnih faktora u pokretanju razvoja svake delatnosti na nivou regije, a time i razvoju turizma. Značaj tehnologije je za razliku od proizvodnih organizacija u procesu proizvodnje, manje izražen u delatnosti turizma. $U$ pogledu postojeće infrastrukture turističkih preduzeća i organizacija, ona može biti osnova za stvaranje nove, a time i bolje infrastukturne mreže (Vojnović i dr., 2012).

Praksa Evropske unije je pokazala da teritorijalne jedinice (opštine, gradovi, okruzi, regioni) predstavljaju bolji okvir za realizaciju jednakog razvoja, solidarnosti, kao i zaštite životne sredine. U korist te činjenice govori $\mathrm{i}$ to da je jedna trećina budžeta Evropske unije namenjena regionalnoj politici, a osim regiona, u budžet su uključene i ostale teritorijalne jedinice. Jednak razvoj doprinosi političkoj i socijalnoj stabilnosti zemlje, stvarajući uslove za brži ekonomski razvoj svih teritorijalnih jedinica.

Pomenuto ukazuje da teritorijalne jedinice podstiču konkurentnost ruralne zajednice. Ruralni razvoj je složen socio-ekonomski segment i često se naglašava potreba za integralnim razvojem ruralnih područja, što bi značajno razvilo socio-kulturnu, institucionalnu, ekološku i drugu dimenziju regionalnog $i$ lokalnog razvoja države, te je i uloga države veoma značajna u ovom polju, jer je lokalni ruralni razvoj deo ukupnog društvenog razvoja.

Samim tim, razvoj na lokalnom nivou je glavni društveni izazov i s obzirom da specifičnosti problema razvoja lokalnih ruralnih područja variraju, značajno je uvođenje novih ideja u formalnu strategiju za razvoj i jačanje socijalnog kapitala lokalnih zajednica, koje zajedno sa drugim oblicima kapitala, povećavaju 
konkurentnost lokalne zajednice i prouzrokuju pozitivne društvene promene.

\section{ODRŽIVI TURIZAM / SUSTAINABLE TOURISM}

Turizam se razvio u globalni fenomen $i$ jedan je od najvažnijih privrednih sektora i društvenih aktivnosti našeg vremena. Kao takav, turizam predstavlja glavni izvozni sektor za mnoge zemlje, pre svega razvijene, ali i za zemlje u razvoju (Petković i Pindžo, 2012). Razvoj turizma je doneo i nove težnje i potrebe modernih turista i savremenih trendova u turizmu. Veliki broj savremenih turista traga za iskustvima koja im pružaju osećaj bliskosti sa lokalnom zajednicom.

Turizam se može smatrati jednom od najznačajnijih socijalno-ekonomskih pojava 20 . veka. Turizam predstavlja jednu od pet izvoznih kategorija u $83 \%$ svih zemalja sveta i glavni izvoz zarade u gotovo $38 \%$ ukupnog broja zemalja (Premović i dr., 2014). Njegova brza ekspanzija ima direktan uticaj na životnu sredinu i socio - kulturni uticaj u mnogim oblastima. Uloga zelene ekonomije usmerena je na održivi razvoj, odnosno usmerena je na strategiju ostvarivanja prosperiteta za ljude i Planetu, danas i sutra (Ivanović i dr., 2016).

Savremeni turizam ima mnogobrojne funkcije koje su u značajnoj meri povezane i kao takav, turizam uvek ima široko dejstvo, kako na privredni, tako i na ukupni društveni život. Činjenica je da se mnoge zemlje opredeljuju za razvoj turizma, imajući u vidu njegove ekonomske uticaje. Pretpostavka za razvoj turizma nalazi se u činjenici raspoloživosti atraktivnih, komunikativnih i receptivnih faktora. Ukoliko zemlja raspolaže ovim faktorima, sasvim je jasno da jedna od delatnosti koja tu zemlju može da uključi u međunarodnu razmenu, treba da bude i turizam, što se posebno odnosi na razvoj inostranog turizma (Bakić i Hrabovski Tomić, 2010).

Masovni razvoj turizma u prethodnom periodu, izazvao je veliki broj negativnih posledica po životnu sredinu, što je ukazalo na potrebu stavljanja ove delatnosti pod koncept održivog razvoja. U slučaju turizma, ali i drugih delatnosti, pokazalo se da zaštita životne sredine ne može da bude izolovana, jer je ona sastavni deo razvojnog procesa, a time i privrednog razvoja. Samim tim, turizmu je potreban održivi razvoj, jer turizam ima posebnu poziciju u doprinosu, koji pruža sveukupnom održivom razvoju. Prvenstveno, to je zbog dinamike i rasta, kome je ova delatnost podložna, kao i ekonomskih efekata, putem kojih utiče na veliki broj zemalja i lokalnih destinacija, ali i zbog karaktera turizma, koji podrazumeva brojne i posebne veze posetilaca, turističke privrede, životne sredine i lokalne zajednice (Stojanović, 2011).

Održivi razvoj se može razumeti samo u okviru stalnog traganja za boljim rešenjem, tako da on predstavlja permanentni proces koji treba da obezbedi odgovore na promene nastale u okviru turističke destinacije, jer ni jedan proces nije konačan.

Poslednjih decenija, turizam ima sve veću ulogu u privrednom i društvenom razvoju mnogih zemalja, ali i u svakodnevnom životu savremenog čoveka. Broj destinacija koje nude svoje turističke proizvode na turističkom tržištu raste, što dovodi do intenziviranja konkurencije (Ubavić, 2015).

Pored edukacije korisnika turističkih usluga, javlja se potreba da preduzeća, koja posluju u okviru turističkih odredišta, preuzmu ulogu u očuvanju upravo tih resursa, prostora na kojima obavljaju svoju privrednu delatnost, ali istu odgovornost treba da snosi pojedinac koji tu privremeno ili stalno boravi. Zakonska ograničenja predstavljaju jedan od mehanizama, putem kojih se direktno može delovati na privredne subjekte i njihove aktivnosti.

Veliku ulogu, a moguće i najveću, predstavlja pravovremena informisanost i edukacija. Formiranje svesti o važnosti očuvanja životne sredine u vremenu kada krilatica „progres“ predstavlja jedini logičan izbor u privrednom okruženju, treba da bude put ka postizanju održivog razvoja u svim segmentima ekonomije.

\section{ZNAČAJ IMPLEMENTACIJE ODRŽIVOG RAZVOJA U TURIZMU / THE IMPORTANCE OF IMPLEMENTATION OF SUSTAINABLE DEVELOPMENT IN TOURISM}

Principe održivog razvoja moguće je implementirati ukoliko postoje definisani ciljevi šta se želi postići u okviru turističke destinacije. Takve ciljeve je moguće ostvariti putem primene sredstava održivog razvoja. To je moguće postići u okviru definisanih sredstava za primenu održivog razvoja.

Turizam se pokazao kao aktivnost koja oživljava kulturu i tradiciju, kao i da je sam po sebi podsticaj, za bolje razumevanje među ljudima i bolju svesnost na globalnom planu. Nema održivog razvoja bez socijalne jednakosti, nema rasta bez adekvatnog rukovođenja našim prirodnim resursima, od koje zavise naše ekonomije (Ivanović i dr., 2015). Da bi turizam postao održiv potrebno je primeniti principe održivog razvoja, koji bi se kroz operacionalizaciju primenili na turističkoj destinaciji. Jegdić, ali i drugi autori ističu četiri osnovna principa, zasnovana na četiri stuba održivosti: ekonomskoj, ekološkoj, kulturnoj i socijalnoj održivosti (Jegdić, 2011).

$\mathrm{U}$ tom pogledu, turizam se razvio u globalni fenomen i jedan je od najvažnijih privrednih sektora i društvenih aktivnosti našeg vremena. Kao takav, turizam predstavlja glavni izvozni sektor za mnoge zemlje, pre svega razvijene, ali i za zemlje u razvoju (Petković i Pindžo, 2012). Razvoj turizma je doneo i 
nove težnje i potrebe modernih turista i savremenih trendova u turizmu. Veliki broj savremenih turista traga za iskustvima koja im pružaju osećaj bliskosti sa lokalnom zajednicom.

Iz tog razloga, turizam se može smatrati jednom od najznačajnijih socio - ekonomskih pojava 20. veka. Njegova brza ekspanzija ima direktan uticaj na životnu sredinu i socio - kulturni uticaj u mnogim oblastima. Uloga zelene ekonomije usmerena je na održivi razvoj, odnosno usmerena je na strategiju ostvarivanja prosperiteta za ljude i Planetu (Ivanović i Perić, 2016).

Razvoj svih oblika selektivnog ekoturizma obezbeđuje održivost u razvoju turističke privrede (Premović i dr., 2014). Poslednjih decenija, turizam ima sve veću ulogu u privrednom i društvenom razvoju mnogih zemalja, ali i u svakodnevnom životu savremenog čoveka. Broj destinacija koje nude svoje turističke proizvode na turističkom tržištu raste, što dovodi do intenziviranja konkurencije (Ubavić, 2015).

Turizam, kao jedan od najvećih pokretača razvoja svetske privrede, zahteva neophodnost uspostavljanja održivog i odgovornog razvoja, u cilju svih bitnih vrednosti okruženja, s obzirom na to da se današnje društvo susreće sa dva najvažnija problema, klimatskim promenama i siromaštvom. Turizam kao jedan od motora ekonomskog razvoja, doprinosi smanjenju siromaštva, a to je najizraženije u manje razvijenim zemljama i ruralnim predelima što predstavlja pozitivni efekat. Međutim, postoje mnogi negativni efekti od turizma ukoliko se ne zasniva na principima održivog razvoja, a te negativne posledice su najvidljivije u oblastima u kojima je razvijen masovni oblik turizma.

Prema podacima Svetske turističke organizacije (UNWTO) turizam predstavlja jednu od najbrže rastuće privredne grane ekonomije. U 2017. godini broj međunarodnih dolazaka porastao je za $7 \%$ u odnosu na prethodnu godinu i dostigao broj od 1.322 miliona. U 2018. godini očekivani rast od 4\%, predstavljao je očekivani rast oko $3.8 \%$ rasta u desetogodišnjem periodu između 2010-2020.godine, uključujući i projektovani rast u 2018. i 2019. godini (UNWTO).

Turizam zbog svog ubrzanog razvoja i nemogućnost da se adekvatno odgovori na date promene, generiše mnoge štetne efekte po životnu sredinu. Povećan broj međunarodnih, ali i domaćih putovanja, direktno se vezuje za povećanje emisije štetnih gasova i stvaranje staklene bašte, što predstavlja jedan od uzroka klimatskih promena i reakcije prirode na posledice nekontrolisanih privrednih aktivnosti.

Mnoge zemlje svoju privredu zasnivaju, upravo, na turističkoj delatnosti. U mnogim zemljama sveta, turizam predstavlja izuzetno značajnu privrednu granu koja je u stalnoj ekspanziji. U tom smislu, svedoci smo da su klimatske promene stvarnost, da korišćenje obnovljivih resursa nije dovedeno na nivo samoodrživosti, da se sve više eksploatišu neobnovljivi resursi, čime se direktno utiče na smanjenje resursa za buduće generacije.

$\mathrm{Na}$ turističkom tržištu, poslovanje zahteva percepciju interesa ponude i tražnje na mikro i na makro nivou, s tim da je težnja na tržištu usmerena na plasiranje turističkih proizvoda, koji omogućavaju:

- ostvarenje cilja poslovanja i

- satisfakciju obe strane - ponude i tražnje (Vuković, 2018).

Turizam, kao jedna od ključnih pokretačkih snaga ekonomskog i privrednog razvoja, izložen je velikom broju rizika (Đorđević, 2018). Često se definiše kao sektor privrede, koji se bavi inoviranjem, ali i proizvodnjom turističkih proizvoda i usluga. Sektor privrede je izuzetno složen s obzirom na to da se turistički proizvodi i akteri konstantno menjaju, zbog promena spoljašnjih snaga (Ilić i Nikolić, 2018).

Jedan od glavnih ciljeva savremenog društva jeste upravo pronalaženje mehanizma koji treba da obezbedi očuvanje životne sredine, smanji upotrebu prirodnih resursa, ali i da obezbedi društvenu i socijalnu pravdu, a turizam kao vodeća ekonomija u svetu treba da da svoj doprinos sveukupnom blagostanju.

Iz tog razloga, koncept održivog razvoja ima za cilj da podrži sam način življenja, zaštitu životne sredine, racionalno korišćenje resursa, socijalnu pravdu u raspodeli resursa, mogućnost izbora sadašnjih i budućih generacija da ostvare svoja prava, kao i uravnoteženi razvoj. To je koncept koji u sebi integriše ekološku, socio-kulturnu i ekonomsku komponentu razvoja, a mnogi mu dodaju i institucionalnu komponentu (Jegdić, 2011).

\section{FUNKCIJA MENADŽMENTA U ODRŽIVOM RAZVOJU / MANAGEMENT FUNCTION IN SUSTAINABLE DEVELOPMENT}

Turistička delatnost, kao jedna od kategorija zelene ekonomije, u funkciji je održivog razvoja i u tom smislu, turizam nije izuzetan samo zbog načina na koji je prihvaćen, već on ima posebnu poziciju u doprinosu, koji pruža sveukupni održivi razvoj. Turističke potrebe interpoliraju se u sistem čovekovih potreba, na osnovu uslova, u kojima se formiraju, a njihov ekonomski izraz manifestuje se u potrošnji, veličini, strukturi, dinamičnosti i drugim karakteristikama. 
Turizam je jedna od najdinamičnijih industrija $u$ globalnoj ekonomiji. Zbog ubrzanog tempa savremenog zagađenja života i životne sredine, sve veći broj ljudi žele da provedu svoje vreme u prirodi, u kontakt sa autentičnim načinom života. Turistička ponuda je sve više usmerena prema razvoju raznih oblika prirodnog turizma. Ipak, bez obzira na oblike u kojima se razvija, turizam mora da ispunjava kriterijume održivosti. Privlačenje posetilaca i investitora, kao i uključivanje lokalnih preduzetnika u turizam i komplementarne aktivnostima, doprinosi ekonomskom razvoju i socijalnoj stabilnosti lokalne zajednice. Međutim, razvoj turizma, ako se neadekvatno upravlja, može imati negativni uticaj na životnu sredinu i kulturne vrednosti (Belsoy and Korir, 2012).

Povećana upotreba resursa i uticaj na životnu sredinu, koji su povezani sa sve većom globalnom populacijom i ubrzavanjem razvoja, učinili su očiglednim da "uobičajeno poslovanje“" nije dovoljno dobro da bi se dostigla održiva budućnost (Bocken et al., 2014). Mnogi istraživači su postigli konsenzus da se održivi razvoj ekonomije i društva ne može dogoditi bez održivog razvoja organizacija. Iz tog razloga, kompanije treba da integrišu održivost u srži svoje organizacije. Održivost, upravljanje korporacijskom održivošću i upravljanje društvenom odgovornošću postaju ključni faktori u poslovanju (Weller, 2020).

Upravljanje održivosti i njegovo integrisanje u organizacije mogu se analizirati iz različitih perspektiva. U tom pogledu, za održivi razvoj, u pogledu funkcije menadžmenta, od značaja je (Broman et al., 2017):

- strateško razmišljanje za održivi razvoj,

- strategija održivosti i integracija održivosti u biznisu,

- organizacioni dizajn i organizacione promene za održivost i

- održivi poslovni modeli.

Prema mnogim istraživanjima, pokazalo se da organizacije, odnosno kompanije moraju integrisati održivost na svim nivoima i u svim odeljenjima kompanije, što znači da se moraju promeniti i korporativna arhitektura i kultura. U nekim slučajevima, kompanije neće biti u mogućnosti da doprinesu održivom razvoju bez promene osnovne poslovne politike. Ipak, pojedinačna posvećenost, jedan je od pokretača implementacije održivosti. Da bi se uspešno izgradili procesi održivosti, potrebno je razviti i primeniti nove upravljačke kompetencije i komplementarne modele upravljanja i organizacije (Broman et al., 2017).

Ukoliko nisu uspostavljene gotove strukture za upravljanje održivosti, pojedinci igraju važnu ulogu u organizacionom učenju vezanom za održivost $i$ pokreću promene za poboljšanje održivosti. Najvaž- nije kompetencije organizacija i zaposlenih u njima, za promenu održivosti su (Heiskanen et al., 2016):

- sistemsko razmišljanje,

- međuljudske kompetencije,

- anticipativne kompetencije,

- strateške kompetencije,

- konkretne kompetencije i

- veštine delovanja.

S tim u vezi, kompanije treba da postave organizaciju na način da dostignu svoje ambicije održivosti i na taj način integrišu održivost u organizaciju, odnosno da formiraju višefunkcionalne timove, postavljaju jasne ciljeve i ključne pokazatelje rada. Vrhovni menadžment i odeljenja za odnose sa javnošću i komunikacije treba da budu snažno uključeni u upravljanje održivosti, pokazujući ne samo njihovu stratešku važnost, već značajnu važnost sa aspekta poštovanja komunikacije i reputacije kompanije.

Prema istraživanjima Šaltegera i Zvezdova o najvećim kompanijama u jedanaest zemalja: Španiji, Belgiji, Velikoj Britaniji, Francuskoj, Nemačkoj, SADu, Japanu, Švajcarskoj, Mađarskoj, Koreji i Australiji, utvrđeno je da kompanije u svim zemljama imaju organizacione jedinice u proseku za promociju održivosti ili barem kao neutralne prema njima (Schaltegger and Zvezdov, 2015).

Sveukupno, međunarodni rezultati pokazali su neverovatno slične prakse upravljanja održivosti u razvijenim zemljama. Odeljenja koja su u nemačkim kompanijama identifikovana kao najmanje zabrinuta i najmanje uključena u upravljanje održivošću, bila su odeljenja finansijskog i menadžerskog računovodstva. Ova odeljenja moraju biti uključena u upravljanje održivosti kako bi se održivost integrisala u ekonomske korporativne odluke (Schaltegger et al., 2012). Finansijske računovođe mogli bi delovati selektivno, pružajući informacije donosiocima odluka višeg nivoa. Takođe bi mogli pružiti svoju stručnost u prevođenju rezultata računovodstva održivosti u jezik upravljanja ili čak biti spremni da podrže proces računovodstva održivosti i delovati kao posrednici.

U skladu sa navedenim, osnovni pokretači poslovnih modela održivosti su (Heiskanen et al., 2016):

- zakonski propisi,

- liderstvo,

- organizaciona kultura,

- interes zaposlenih $\mathrm{i}$

- spremnost za implementaciju projekata.

Ipak, najvažniji faktor poslovnih modela održivosti je organizaciona kultura. Organizacionom kulturom se ne može upravljati, ali društvene interakcije koje grade organizacionu kulturu mogu uticati (Linnenluecke i Griffiths, 2010). 
Veličina, obim, struktura i industrija kompanije utiču na prakse upravljanja održivosti, kao pokretače i barijere u integraciji održivosti. Pitanja održivosti moraju biti integrisana u operativno upravljanje i uzeti u obzir u svim aktivnostima, rutinama i procesima, kako bi se razvila održiva organizacija. Integrisanje održivosti na normativnom nivou mora biti prioritet kompanija. Zaposleni u finansijskim i menadžment računovodstvenim odeljenjima već su suočeni sa svojim proširivanjem uloga ili čak dvostrukom ulogom u održivosti implementacionih procesa. S obzirom na raznovrsnost projekata održivosti, sve kompanije treba da se potrude da se angažuju uz održivost upravljačkih aktivnosti.

\section{ZAKLJUČAK / CONCLUSION}

Održivi razvoj je u mnogim aspektima ostao bez konkretnog sadržaja. Njegove interpretacije su se prilagodile prevladavajućem razumevanju dobrog društva, umesto da dovode u pitanje modernu koncepciju onoga što je poželjno i dobrog razvoja. Sa globalne tačke gledišta, održivi razvoj je moguć samo ako građani shvate potrebu da se posvete promeni načina života i navika, radi sopstvenog života. Učešće građana je neophodno i za pronalaženje lokalno pogodnih rešenja za probleme koji se manifestuju na globalnom nivou.

Turizam, kao jedna od najprofitabilnijih privrednih grana, u stalnom porastu proteklih decenija, ima veliku mogućnost za doprinos ukupnom ekonomskom razvoju. Konkurentnost u sektoru turizma postaje najvažniji fakor rasta, kao i razvoja, posebno u zemljama u razvoju. U današnje vreme, veliki broj zemalja, godišnje primi i preko milion turista.

Turizam treba razvijati u skladu sa principima održivosti. Principi održivosti zahtevaju promene u načinu razmišljanja i vrednosti, gde promene moraju da uključuju globalnu međuzavisnost, upravljanje životnim okruženjem, društvenu odgovornost i ekonomsku održivost. Turizam u lokalnom ekonomskom razvoju, ima ključnu ulogu i danas je postao vodeća privredna grana velikog broja zemalja. O tome svedoče prihodi koje one ostvaruju, ali i brojni drugi pokazatelji. Turizam se može sagledati kao jedna vrsta spone, između urbanih sredina i neurbanizovanih oblasti, bogatih različitim prirodnim resursima.

Primarno, turizam se može posmatrati kao privredna grana koja istovremeno promoviše i privredni rast $\mathrm{i}$ jednakost, $u$ tom smislu što uključuje primenu lokalnih dobara, kao i angažovanje lokalne radne snage. S druge strane, u manje razvijenim regionima, lokalna zajednica može imati značajne ekonomskosocijalne dobiti od turizma, te razvoj ove privredne grane može biti važna prekretnica za dalji razvoj na lokalnom nivou.
U pogledu turizma, kao jednog od faktora rasta svetske ekonomije i najveće izvozne industrije, važno je istaći da turizam predstavlja značajan faktor deviznog priliva i izvor je dodatne vrednosti nerazvijenih prostora. U globalnim razmerama, rast turizma je posledica rasprostranjene liberalizacije, koja se u velikoj meri eksponira na svetskom turističkom tržištu.

U dosadašnjem periodu, razvoj turizma se odlikuje globalnom orijentacijom velikih preduzeća, na međunarodnom nivou, kao i njihovim rastom i razvojem, kroz širenje poslovnih aktivnosti u velikim razmerama. Turistička politika mora biti usmerena na obezbeđenje jasnog pravca razvoja, ali prvenstveno na duži rok, ali i da obezbediti klimu, kao i uslove za saradnju zainteresovanih subjekata.

\section{LITERATURA / REFERENCES}

[1] Angelevska-Najdeska, K., Rakicevik, G. (2012). Planning of sustainable tourism development. Procedia - Social and Behavioral Sciences, 44, pp. 210-220.

[2] Bakić, O., Hrabovski Tomić, E. (2010). Turizam - pojmovi, efekti, funkcionisanje, Fakultet poslovne ekonomije, Sremska Kamenica.

[3] Belsoy, J., Korir, J. (2012). Environmental Impacts of Tourism in Protected Areas. Journal of Environment and Earth Science, 2(10), pp. 64-73.

[4] Bocken, N.M.P.; Short, S.W.; Rana, P.; Evans, S. (2014). A literature and practice review to develop sustainable business model archetypes. J. Clean. Prod., 65, pp. 42-56.

[5] Broman, G.; Robèrt, K.H.; Collins, T.J.; Basile, G.; Baumgartner, R.J.; Larsson, T.; Huisingh, D. (2017). Science in support of systematic leadership towards sustainability. J. Clean. Prod., 140, pp. 1-9.

[6] Đorđević, S. (2018). Hedžing primenom vremenskih derivata u zimskom ski turizmu. Ekonomika poljoprivrede, 65(1), str. 125-142.

[7] Heiskanen, E., Thidell, Å., Rodhe, H. (2016). Educating sustainability change agents: The importance of practical skills and experience. $\mathrm{J}$. Clean. Prod., 123, pp. 218-226.

[8] Ilić, I., Nikolić, A. (2018). Implikacije razvoja savremenih tehnologija na sektor turizma Republike Srbije. Ekonomika, 64(1), str. 37-52.

[9] Ivanović V., Gašić M, Perić G. (2016). Zeleni turizam kao deo zelene ekonomije u funkciji buduće održivosti. Ecologica 23 (81), str. 200205.

[10] Ivanović, V., Gašić, M., Plavanski, J., Madžgalj, J. (2015). Priroda kao osnov zelene ekonomije. Ecologica, 78(22), str. 329-333. 
[11] Janković, M., Luburević, V., Šofranac, R. (2017). Održivi turizam kao osnova upravljanja u nacionalnim parkovima u Crnoj Gori, Ekonomika, 63(4), str. 41-51.

[12] Jegdić, V. (2011). Turizam i održivi razvoj, Fakultet za sport i turizam, Novi Sad.

[13] Linnenluecke, M.K., Griffiths, A. (2010). Corporate sustainability and organizational culture. J. World Bus., 45, pp. 357-366.

[14] Lukinović, M., Jovanović, Đ., Jovanović, L. (2017). Održivi razvoj i ekosistemska odgovornost kroz uvođenje etičkih principa u savremeno poslovanje, Ecologica, 24(86), str. 241248.

[15] Ožegović, L., Vučurević, T., Brkanlić, S. (2012). Ekologija - stub održivog razvoja. Evropsko zakonodavstvo, 11(41), str. 45-48.

[16] Petković, G., Pindžo, R. (2012). Turizam i novi ekonomski izazovi. Ekonomika preduzeća, 60(1-2), str. 117-126.

[17] Premović J., Boljević, A. Vujović S. (2014). Agenda 21 - osnovni aspekti održive turističke privrede, Ecologica, 75 (21), str. 21-27.

[18] Radosavac, A., Pejanović, R., Premović, J. (2013). Značaj preduzetništva za razvoj turističke privrede, Agroekonomika, Poljoprivredni fakultet, Univerzitet u Novom Sadu.

[19] Radygin, A., Simachev, Y., \& Entov, R. (2015). The state-owned company: "State failure" or "market failure"?. Russian Journal of Economics, 1(1), pp. 55-80.

[20] Schaltegger, S., Hörisch, J., Windolph, S.E., Harms, D. (2012). Corporate Sustainability Barometer 2012. Praxisstand und Fortschritt des Nachhaltigkeitsmanagements in den größten Unternehmen Deutschlands; Center for Sustainability Management e.V.: Lüneburg, Deutschland.

[21] Schaltegger, S., Zvezdov, D. (2015). Gatekeepers of sustainability information: Exploring the roles of accountants. J. Account. Organ. Chang., 11, pp. 333-361.

[22] Stojanović, V. (2011). Turizam i održivi razvoj, Univerzitet u Novom Sadu, Prirodno matematički fakultet, Novi Sad.

[23] Ubavić, P. (2015). Kreiranje konkurentskog profila Srbije kao turističke destinacije. Škola biznisa, (1), str. 80-97.

[24] UNWTO: https://www.unwto.org/global/pressrelease/2018-01-15/2017-internationaltourism-results-highest-seven-years

[25] Vićentijević, D., Aćimović, L., Stevanović, S. (2011). Uticaj tehnološkog razvoja na održivi razvoj poljoprivrede i zaštitu životne sredine, Ekonomika poljoprivrede, 58(297-2016-3809), str. 191-203.

[26] Vojnović, B., Cvijanović, D., Stefanović, V. (2012). Razvojni aspekti turističke delatnosti, Institut za ekonomiku poljoprivrede, Beograd, 59(3), str. 557-558.

[27] Vujadinović, S., Pavlović, M., Šabić, D. (2010). Integralni održivi razvoj na primeru lokalne geografske sredine, Glasnik Srpskog Geografskog društva, 90(2), str. 173-187.

[28] Vuković, P. (2018). Formiranje i promocija ruralnog turističkog proizvoda u Republici Srbiji. Ekonomika, 64(4), str. 81-92.

[29] Weller, A. (2020). Exploring practitioners' meaning of "ethics", "compliance," and "corporate social responsibility" practices: A communities of practice perspective. Business \& Society, 59(3), pp. 518-544. 